Volume 2 Nomor 2 Tahun 2020

e-ISSN: 2655-948X

http://u.lipi.go.id/1548306171

\title{
PENGARUH KETEPATAN PENGHITUNGAN KRITERIA KETUNTASAN MINIMAL (KKM) PADA MATA PELAJARAN PENDIDIKAN AGAMA ISLAM TERHADAP KEBERHASILAN BELAJAR SISWA DI MI MIFTAHUL ULUM SOOKO WRINGINANOM GRESIK
}

\author{
Afifah \\ STAI Taruna Surabaya \\ e-mail: afifahsyahira48@gmail.com
}

Diterima: 05 November 2020 | Direvisi: 27 November 2020 | Disetujui: 29 November 2020

(C) 2018 Program Studi Pendidikan Agama Islam Fakultas Agama Islam Universitas Islam Malang

\begin{abstract}
Education is an effort that must be done by everyone who wants success in his life, one of the things that can be done with educators, students, leaders of education units, and parents to support and determine the success of students is to make efforts to achieve the Minimum Completeness Criteria ( KKM) by maximizing the learning and assessment process. So researchers conducted research in MI Miftahul Ulum Sooko Wringinom Gresik with the title the effect of the accuracy of calculating the minimum completeness criteria (KKM) on student learning success, in this case the researchers used a quantitative approach and used the Kendall Tau correlation, where this correlation was used to look for relationships and test hypotheses between two or more variables. The research technique used in this study was observation, questionnaire, documentation. Based on the results of research conducted, the accuracy of the calculation of Minimum Completeness Criteria (KKM) is in the good category with a percentage of $84.4 \%$, the results of student learning values are in the good category with the percentage results amounting to 83.3\%, as for the effect of Accuracy in Completion Criteria At a minimum (KKM) on student learning success, there is a significant correlation in the coefficient interval of $0.60-0.799$ which means it shows a strong relationship level.
\end{abstract}

Keywords: minimum completeness criteria (KKM), learning success

\begin{abstract}
Abstrak
Pendidikan adalah upaya yang harus dilakukan oleh setiap orang yang menginginkan keberhasilan dalam hidupnya, salah satu hal yang bisa dilakukan bersama pendidik, peserta didik, pimpinan satuan pendidikan, dan orang tua untuk mendukung dan menentukan keberhasilan peserta didik adalah dengan melakukan upaya pencapaian Kriteria Ketuntasan Minimal (KKM) dengan memaksimalkan proses pembelajaran
\end{abstract}

This work is licensed under Creative Commons Attribution Non Commercial 4.0 International License Available online on: http://riset.unisma.ac.id/index.php/fai/index 
dan penilaian. Maka peneliti melakukan penelitian di MI Miftahul Ulum Sooko Wringinanom Gresik dengan judul pengaruh ketepatan penghitungan kriteria ketuntasan minimal (KKM) terhadap keberhasilan belajar siswa, dalam hal ini peneliti menggunakan pendekatan kuantitatif dan menggunakan korelasi Kendall Tau, dimana korelasi ini digunakan untuk mencari hubungan dan menguji hipotesis antara dua variable atau lebih. Teknik penelitian yang digunakan dalam penelitian ini adalah dengan observasi, kuesioner, dokumentasi. Berdasarkan hasil penelitian yang dilakukan, ketepatan perhitungan Kriteria Ketuntasan Minimal (KKM) berada pada kategori baik dengan prosentase yang berjumlah 84,4\%, hasil nilai belajar siswa berada pada kategori baik dengan hasil prosentase berjumlah 83,3\%, adapun pengaruh Ketepatan Perhitungan Kriteria Ketuntasan Minimal (KKM) terhadap keberhasilan belajar siswa, ada korelasi yang signifikan berada pada interval koefisien 0,60 - 0,799 yang berarti menunjukkan tingkat hubungan yang kuat.

Kata Kunci: kriteria ketuntasan minimal (KKM), keberhasilan belajar

\section{Pendahuluan}

Peran vital Pendidikan dalam membentuk bangsa cerdas dan beradab. Oleh karenanya wajar bilmana tuntutan bagi orang yang terlibat dalam pendidikan olehnya untuk melakukan kerjasama secara maksimal dengan tanggung jawab penuh dan loyalitas tinggi demi capai mutu pendidikan. Bangsa tangguh, mandiri, berdaya saiang, dan berkarakter dapat dibentuk melalui pendidikan. Peran pokok Pendidikan dipandapng sebagai aspek yang dapat membentuk bahkan mempersiapkan generasi muda mendatang. Maka dari itu posisi mendidikan dalam kehidupan manusia menjadi vital, mengingat nilai-nilai dasar ideal terkandung didalamnya yang dapat menjadi kekuatan atau sumber kebenaran serta mengantarkan bangsa mencapai cita-citanya. Nilai dasar tersetersebut menjadi standarisasi dalam evaluasi penyelenggaraan pendidikan (Mohammad Syaifuddin : 2017).

Pendidikan sesuai Undang-Undang No. 20 tahun 2003 dalam Sisdiknas membentuk kesadaran manusai untuk belajar agar potensi dirinya dapat dikembangkan berdasarkan penyususnan perencanaan yang matang. Peran Pendidikan sangat strategis dalam peningkatan sumber daya manusia dan wujudkan cita-cita bangsa serta kesejahteraan umum, termasuk mencerdaskan kehidupan bangsa (Wiyono, 2017: 143). Tujuannya pengembangan potensi siswa untuk dijadikan manusia memiliki iman dan taqwa kepada tuhan yang maha Esa, berakhlak mulia, berilmu, kreatif, kreatif, cakap, sehat, dan memiliki kemandirian. Oleh karenanya penanaman ilmu agama sejak dini begitu penting untuk mewujudkan tujuan Pendidikan (Hidayatullah, 2020: 261). Hal ini sesuai dengan 
definisi pendidikan agama Islam, yaitu membangun kesadaran siswa melalui perencanaan matang untuk mempersiapkannya mengenal, memahami, menghayati, mengimani, bertaqwa, berakhlak mulia dan mengamalkan ajaran Islam sesuai dengan Al-quran dan Hadis, melalui pengajaran, bimbingan, latihan maupun pengalaman.

Dilihat dari perencanaan aspek yang terpenting dalam melakukan desain pembelajaran adalah siswa sebagai pertimbangan utama. Apapun rencana pembelajaran yang digunakan guru seperti model, strategi, metode dan lainnya aspek yang menjadi pertimbangan penting adalah siswa. Ada beberapa aspek dalam perencanaan, salah satunya adalah potret karakteristik siswa. Sebelum guru melakukan desain pembelajaran maka diharuskan mengetahui tantang kondisi siswanya. Dalam memotret kondisi siswa maka salah satu bnetuknya yang lazim digunakan adalah melakukan analisis kreteria ketuntasan belajar siswa atau dikenal dengan KKM. Kriteria Ketuntasan Minimal (KKM) adalah kriteria ketuntasan belajar (KKB) yang ditentukan oleh satuan pendidikan (Peraturan Menteri Pendidikan Nasional Nomor 20 Tahun 2007 Lampiran butir A. 10).

Objektifitas perhitungan Kriteria Ketuntasan Minimal (KKM) wajib disesuaikan dengan kondisi pembelajaran di sekolah/madrasah, mengingat kondisi pembelajaran sebagai potret keadaan peserta didik secara faktual. KKM juga berhubungan dengan penggunaan standar evaluasi, sehingga tidaklah mudah untuk menebaknya berdasarkan keinginan guru meupun kehendak Kepala Sekolah. Pengambilan nilai KKM berdasarkan tiga hal, yakni daya dukung, kompleksitas materi, dan intake (kemampuan) siswa. Ketiganya diramu berdasarkan standar kompetensi, kompetensi dasar, dan indikator sampai memunculkan KKM mata pelajaran tertera di rapor siswa.

Seringkali dijumpai kasus gagal faham guru terhadap esensi KKM dan menganggap KKM memiliki kesamaan dengan nilai rata-rata. Anggapan mereka berdasarkan pengambilan nilai tertinggi dari nilai rata-rata untuk menentukan KKM. Padahal tidak demikian, KKM merupakan nilai minimum atau nilai terendah yang wajib dicapai siswa dalam menyelesaikan proses belajarnya. Penguhitungan KKM haruslah oobjektif tidak sekedar menebak untuk menaikkan kelas.tingkatan lembaga atas dasar gengsi. KKM tidaklah perlu menyamakan dengan nilai tertinggi atau terendah dari nilai rata-rata. Idealnya peserta didik mampu melampauinya dan dapat dimanfaatkan untuk mengidentifikasi kesulitan siswa dalam menuntaskan pembelajarannya.

Tujuan KKM untuk meningkatkan mutu atau kualitas pendidikan yang dapat dimanfaatkan sebagai acuan guru dalam kegiatan belajar mengajar. KKM dapat pula 
menjadikan beban peserta bila angka yang ditetapkan sangat tinggi tanpa memperhatikan aspek input sumber daya manusia maupun kualitas proses pembelajaran dan berdasarkan keinginan beberapa pihak tanpa aspek identifkasi dan pertimbangan matang. Dalam menentukan Kriteria Ketuntasan Minimal (KKM) di MI Miftahul Ulum Sooko Wringinanom Gresik dengan berbasis mata pelajaran dimana sekolah menentukan berapa nilai KKM yang sesuai dari setiap mata pelajaran dan akan dikoordinasi dengan masing-masing wali kelas dalam KKM setiap mata belajaran kelas rendah dan kelas tinggi pun berbeda.

Beberapa studi tentang KKM menunjukkan adanya keterkaitan antara KKM dan hasil belajar. Salah satunya hasil penelitian Lailatul Furhah (2013) Study tentang penentuan Krtiteria Ketuntasan Minimal (KKM) dan Kesesuaian Hasil Belajar Siswa Kelas VII SMP Negeri 13 Surabaya pada Mata Pelajaran Pendidikan Agama Islam (PAI). Hasil penelitian ini menggunakan metode kualitatif dimana dalam mata pelajaran PAI dalam perhitungannya sesui dengan hasil belajar siswa yang sebelumnya mngalami penurunan sekarang sudah mulai stabil. Berdasarkan latar belakang yang telah diuraikan diatas, maka penulis merasa tertarik untuk mengadakan penelitian dengan judul "Pengaruh ketepatan penghitungan Kriteria Ketuntasan Minimal (KKM) terhadap keberhasilan belajar siswa di MI Miftahul Ulum Sooko Wringinanom Gresik".

\section{Metode}

Dalam hal ini peneliti menggunakan pendekatan kuantitatif dan menggunakan korelasi Kendall tau, dimana korelasi ini digunakan untuk mencari hubungan dan menguji hipotesis antara dua variable atau lebih. Teknik penelitian yang digunakan dalam penelitian ini adalah dengan observasi, kuesioner, dokumentasi. Populasi dalam penelitian ini adalah peserta didik MI Miftahul Ulum Sooko Wringinanom Gresik ada 1-6 kelas yang terdiri dari 9 rombel dengan total 232 siswa.

\begin{tabular}{|c|c|c|}
\hline NO & Populasi & Jumlah \\
\hline 1. & Guru & 13 Orang \\
\hline 2. & Siswa & 200 Siswa \\
\hline 3. & Rombel & 9 Rombel \\
\hline
\end{tabular}




\section{Hasil dan Pembahasan}

\section{Kriteria Ketuntasan Minimal (KKM)}

Pendidik, siswa dan orang tua bersepakat menjadikan KKM menjadi acuan pembelajaran. Oleh karenanya berhak mengetahui bagi pihak yang berkepentingan dalam penilaian sekolah. Keberadaan sosialisasi KKM juga menjadi perlu untuk memberikan informasi kepada pihak yang terlibat dalam Pendidikan. Termasuk pencantuman KKM secara transparan oleh stakeholders pendidikan melalui laporan hasil belajar (HLB), sebagai kontrol dan tindak lanjut peserta didik baik dirumah, sekolah maupun masyarakat oleh pighak yang terlibat dalam Pendidikan.

Data observasi dalam penelitian ini berupa pernyataan-pernyataan tentang ketepatan perhitungan Kriteria Ketuntasan Minimal (KKM) terhadap keberhasilan belajar di MI Miftahul Ulum Sooko, observasi ini dilakukan oleh peneliti kepada kepala sekolah dan para guru. Kriteria ketuntasan belajar setiap indikator yang telah ditetapkan dalam suatu kompetensi dasar berkisar antara 0-100\%. Kriteria ketuntasan belajar maksimalnya adalah 100. Namun, sangat sulit dicapai, sehingga kriteria ideal ketuntasan untuk masing-masing indikator mata pelajaran adalah 75\% (Departemen Agama Provinsi Jawa Timur: Pedoman dan Implementasi Pengembangan KTSP di Madrasah Ibtidaiyah : 2009).

Sebelum melakukan observasi dan kuesioner, peneliti penyusun langkahlangkah sebagai berikut:

a. Peneliti membuat format pengamatan sebagai instrument

b. Instrumen diambil dari indikator teori

c. Intrumen indikator berisi 11 item pernyataan yang harus dinilai

d. Penilaian instrumen indikator dilakukan oleh peneliti

e. Peneliti memberi tanda checklist (?) pada setiap butir item pernyataan

f. Setiap butir item pernyataan memiliki bobot nilai yang bervarian, diantaranya:

1) Sangat Baik diberi skor 4

2) Baik diberi skor 3

3) Cukup diberi skor 2

4) Kurang Diberi Skor 1

Tabel II

Data tentang "Ketepatan Perhitungan KKM"

(Variabel X atau Variabel Independent)

\begin{tabular}{|c|c|c|c|c|c|c|c|c|c|c|c|c|c|}
\hline \multirow{2}{*}{$\begin{array}{c}\text { No } \\
\text { Responden }\end{array}$} & \multicolumn{11}{|c|}{ Pernyataan } & \multirow{2}{*}{ Jumlah } & \multirow{2}{*}{$\%$} \\
\hline & 1 & 2 & 3 & 4 & 5 & 6 & 7 & 8 & 9 & 10 & 11 & & \\
\hline 1 & 4 & 4 & 3 & 4 & 4 & 3 & 4 & 4 & 4 & 3 & 3 & 40 & 91 \\
\hline 2 & 4 & 3 & 3 & 4 & 3 & 3 & 4 & 4 & 4 & 3 & 3 & 38 & 86 \\
\hline
\end{tabular}




\begin{tabular}{|c|c|c|c|c|c|c|c|c|c|c|c|c|c|}
3 & 3 & 4 & 3 & 4 & 4 & 3 & 4 & 4 & 4 & 2 & 3 & 38 & 86 \\
\hline 4 & 4 & 3 & 3 & 3 & 4 & 3 & 4 & 3 & 4 & 4 & 2 & 37 & 93 \\
\hline 5 & 4 & 4 & 3 & 3 & 4 & 3 & 3 & 4 & 4 & 3 & 3 & 38 & 86 \\
\hline 6 & 4 & 3 & 4 & 4 & 3 & 3 & 4 & 3 & 4 & 3 & 2 & 37 & 84 \\
\hline 7 & 3 & 4 & 3 & 2 & 4 & 3 & 3 & 2 & 3 & 4 & 4 & 35 & 80 \\
\hline 8 & 4 & 4 & 3 & 3 & 4 & 3 & 3 & 3 & 3 & 3 & 4 & 37 & 84 \\
\hline 9 & 2 & 3 & 4 & 4 & 4 & 3 & 3 & 3 & 3 & 2 & 4 & 35 & 80 \\
\hline 10 & 3 & 2 & 4 & 4 & 3 & 4 & 4 & 3 & 3 & 3 & 3 & 36 & 82 \\
\hline 11 & 3 & 2 & 4 & 3 & 3 & 4 & 4 & 4 & 4 & 3 & 3 & 37 & 84 \\
\hline 12 & 4 & 3 & 4 & 3 & 3 & 4 & 4 & 4 & 4 & 4 & 3 & 40 & 91 \\
\hline 13 & 2 & 4 & 2 & 3 & 3 & 2 & 4 & 4 & 4 & 4 & 3 & 35 & 80 \\
\hline
\end{tabular}

Berdasarkan data diatas, langkah selanjutnya yang penulis lakukan adalah menentuka kualifikasi, frekuensi dan prosentase dari lembar kuesioner Ketetapan Perhitungan KKM guru. Menentukan kualifikasi dan interval nilai dengan cara menentukan range, berdasarkan data di atas bahwa nilai tertinggi adalah 44 dan nilai terendah adalah 11

$$
\begin{aligned}
\mathrm{R} & =\mathrm{H}-\mathrm{L}+1 \\
& =44-11+1 \\
& =34
\end{aligned}
$$

Hasil range tersebut dapat diketahui bahwa interval nilainya adalah :

$$
\mathrm{i}=\frac{\text { range }}{\text { jumlah interval }}=\frac{34}{3}=11
$$

Tabel III

Interval Nilai Ketetapan Perhitungan KKM

\begin{tabular}{|c|c|c|}
\hline NO & INTERVAL & KETERANGAN \\
\hline 1 & $11-21$ & Kurang Baik \\
\hline 2 & $22-32$ & Cukup Baik \\
\hline 3 & $33-44$ & Baik \\
\hline
\end{tabular}

Tabel IV

Distribusi Frekuensi dan Prosentase

\begin{tabular}{|c|c|c|c|}
\hline NO & INTERVAL & FREKUENSI & PROSENTASE \\
\hline 1 & $11-21$ & 9 & $69,2 \%$ \\
\hline 2 & $22-32$ & 9 & $69,2 \%$ \\
\hline 3 & $33-44$ & 10 & $76,9 \%$ \\
\hline
\end{tabular}


Jika nilai range tersebut $<34$ maka tidak termasuk dalam perhitungan Kendal Tau, dan jika nilai range $>34$ maka masuk dalam perhitungan Kendal tau.

Setelah mendata jumlah jawaban setiap pernyataan. Maka bagaimana tingkat ketepatan penghitungan KKM di MI Miftahul Ulum Sooko Wringinanom Gresik dapat diketahui dengan memprosentase banyaknya nilai hasil jawaban dari 11 butir pernyataan. Setelah mendata jumlah jawaban setiap pernyataan maka untuk mengetahui tingkat ketepatan penghitungan KKM di MI Miftahul Ulum Sooko Wringinanom Gresik, peneliti menggunakan rumus prosentase. Adapun perhitungannya sebagai berikut:

$$
\begin{aligned}
\mathrm{P} & =\frac{f}{N} \times 100 \% \\
& =\frac{483}{572} \times 100 \% \\
& =84,4
\end{aligned}
$$

Dari hasil perhitungan yang diperoleh dari hasil observasi dan kuesioner yang dibagikan ke 13 ressponden tingkat ketepatan perhitungan KKM di MI Miftahul Ulum Sooko yang dinilai oleh peneliti secara umum dapat digambarkan bahwa tingkat ketepatan perhitungan KKM di Miftahul Ulum Sooko, berada pada kategori baik. hal ini dapat dilihat dari hasil prosentase observasi siswa yang berjumlah $84,4 \%$. Apabila diinterpretasikan pada tabel standar prosentase amak prosentase 76\% - 100\% yang dikategorikan baik.

\section{Keberhasilan Belajar}

UNESCO membangun konsep belajar empat pilar pendidikan yang dituntutkan terhadap semua satuan pendidikan untuk dapat mengebangkannya di masa saat ini maupun masa mendatang, diantaranya:

a. learning to know (belajar untuk mengetahui), artinya seseorang yang memiliki tekad belajar harus mendapatkan wawasan pengetahuan melalui berbagai kegiatan yang dilakukan di sekolah.

b. learning to do (belajar untuk melakukan sesuatu), merupakan peserta didik yang sedang belajar diberikan kesempatan untuk melakukan aksi terampil agara dapat mengembangkan pengetahuannya.

c. learning to be (belajar untuk menjadi seseorang), adalah peserta didik dengan pengetahuan yang dimiliki harus mempunyai cita-cita dan mimpi untuk menjadi apa.

d. learning to live together (belajar untuk menjalani kehidupan bersama), artinya tujuan dari belajar pada akhirnya untuk mempersiapkan kehidupan di masa mendatang dan berkumpul dengan banyak orang (Bambang Warsita (2008: 62)). 
Dalam proses pebelajaran tentu terdapat indikator keberhasilannya. Sebagaimana pandangan salah satu pakar Pendidikan (Djamarah, 2006: 106) indikatornya meliputi:

a. Pencapaian prestasi tinggi baik perseorang maupun kelompok atas pemahaman terhadap materi pelajaran

b. Pencapaian siswa terhadap perilaku yang diajarkan sesuai tujuan pembelajaran atau pendidikan baik perseorangan maupun kelompok.

Oleh karenanya kemampuan peserta didik dalam menyerap materi pelajaran maupun mengamalkan perilaku yang diajarkan menjadi indikator keberhasilannya dalam kegiatan pembelajaran baik dilakukan perseorangan maupun kelompok.

Adapun data observasi dalam penelitian ini berupa pernyataan-pernyataan tentang bagaimana keberhasilan belajar siswa di MI Miftahul Ulum Sooko, observasi dan pembagian kuesioner ini dilakukan oleh peneliti kepada siswa yang merupakan sampel respoden yaitu kelas 1 sampai 6. Sebelum melakukan observasi dan membagikan kuesioner, peneliti penyusun langkah-langkah sebagai berikut:

a. Peneliti membuat format pengamatan sebagai instrumen

b. Instrumen diambil dari indikator teori

c. Intrumen indikator berisi 10 item pernyataan yang harus dinilai

d. Penilaian instrumen indikator dilakukan oleh peneliti

e. Peneliti memberi tanda checklist (?) pada setiap butir item pernyataan

f. Setiap butir item pernyataan memiliki bobot nilai yang bervarian, diantaranya:

1) Sangat Baik diberi skor 4

2) Baik diberi skor 3

3) Cukup diberi skor 2

4) Kurang diberi skor 1

Tabel V

Data tentang "Keberhasilan Belajar Siswa" (Variabel Y atau Variabel Dependent)

\begin{tabular}{|c|c|c|}
\hline $\begin{array}{c}\text { No. } \\
\text { Responden }\end{array}$ & Nilai & \% \\
\hline 1 & 77,7 & 77,7 \\
\hline 2 & 78,8 & 78,8 \\
\hline 3 & 83,3 & 83,3 \\
\hline 4 & 85,3 & 85,3 \\
\hline 5 & 90,4 & 90,4 \\
\hline 6 & 88,7 & 88,7 \\
\hline 7 & 90,7 & 90,7 \\
\hline
\end{tabular}

Andragogi: Volume 2 Nomor 2, 2020 


\begin{tabular}{|c|c|c|}
8 & 80,8 & 80,8 \\
\hline 9 & 77,8 & 77,8 \\
\hline 10 & 83,3 & 83,3 \\
\hline 11 & 87,2 & 87,2 \\
\hline 12 & 87,4 & 87,4 \\
\hline 13 & 85,3 & 85,3 \\
\hline JUMLAH & $\mathbf{1 0 9 6 , 7}$ & $\mathbf{1 0 9 6 , 7}$ \\
\hline
\end{tabular}

Setelah mendata jumlah jawaban setiap butir soal. Maka Untuk menjawab bagaimana keberhasilan belajar siswa di MI Miftahul Ulum Sooko Wringinaom Gresik dapat diketahui dengan memprosentase banyaknya nilai hasil nilai rata-rata dari 6 kelas d MI Miftahul Ulum Sooko Wringinanom Gresik. Setelah menghitung dari beberapa nilai siswa keberhasilan belajar siswa di MI Miftahul Ulum Sooko Wringinaom Gresik, peneliti menggunakan rumus prosentase

$$
\begin{aligned}
& \mathrm{P}=\frac{f}{N} \times 100 \% \\
& =\frac{1096}{1300} \times 100 \% \\
& =84,3
\end{aligned}
$$

Dari hasil perhitungan yang diperoleh oleh peneliti bahwa keberhasilan belajar siswa di MI Miftahul Ulum Sooko Wringinanom Gresik secara umum dapat digambarkan bahwa bentuk keberhasilan belajar siswa di MI Miftahul Ulum Sooko Wringinanom Gresik berada pada kategori baik, hal ini dapat dilihat dari hasil prosentase observasi siswa yang berjumlah $83,3 \%$. Apabila diinterpretasikan pada tabel standar prosentase amak prosentase 76\% - 100\% yang dikategorikan Baik.

\section{Hubungan Ketepatan Perhitungan Kriteria Ketuntasan Minimal (KKM) terhadap Keberhasilan Belajar Siswa di MI miftahul Ulum Sooko Wringinanom Gresik}

Dalam mencari rumusan ketiga menggunakan rumus Korelasi Kendal tau, untuk membuktikan hasil hipotesa yang diajukan peneliti dalam penelitian ini, maka dibuktikan dengan mencari nilai koefisien korelasi antara variabel X (Keriteria Ketuntasan Minimal) dengan variabel Y (Keberhasilan Belajar). Dalam hal ini, peneliti menggunakan rumus Korelasi Kendal Tau, dengan rumus sebagai berikut:

$$
\tau=\frac{\sum A-\sum B}{\frac{N(N-1)}{2}} . \mathbf{1}
$$

Keterangan:

$\tau \quad$ : Koefesien korelasi Kendal Tau yang besarnya

$$
(-1<\tau<1)
$$

A : Jumlah rangking atas 
B : Jumlah rangking bawah

N : Jumlah anggota sampel (Sugiyono, $2014: 253$ )

Tabel VI

Pedoman untuk Memberikan Interprestasi Koefisien Korelasi

(Sugiyono : 2013)

\begin{tabular}{|c|c|}
\hline INTERVAL KOEFISIEN & TINGKAT HUBUNGAN \\
\hline $0,00-0,199$ & Sangat Rendah \\
\hline $0,20-0,399$ & Rendah \\
\hline $0,40-0,599$ & Sedang \\
\hline $0,60-0,799$ & Kuat \\
\hline $0,80-1,000$ & Sangat Kuat \\
\hline
\end{tabular}

Peneliti menggunakan rumus Korelasi Kendal Tau untuk mengetahui hasil dari analisis data. Adapun perhitungannya sebagai berikut: Adapun hasil analisa korelasi antara variabel X dan variabel Y dari output SPSS 23 dapat dilihat dalam tabel di bawah ini

Tabel VII

Hasil Uji Analisis Korelasi Kendall's Tau

Correlations

\begin{tabular}{|lll|r|r|}
\hline & & $\begin{array}{c}\text { KETEPATAN } \\
\text { PERHITUNGAN } \\
\text { KKM }\end{array}$ & $\begin{array}{c}\text { KEBERHASILAN } \\
\text { BELAJAR }\end{array}$ \\
\hline $\begin{array}{lll}\text { Kendall's } \\
\text { tau_b }\end{array}$ & KETEPATAN & Correlation & 1,000 &, 600 \\
& PERHITUNGAN KKM & Coefficient & &, 048 \\
& & Sig. (2-tailed) & 13 & 13 \\
\cline { 2 - 5 } & KEBERHASILAN & Correlation &, 600 & 1,000 \\
& BELAJAR & Coefficient &, 048 & \\
& & Sig. (2-tailed) & 13 & 13 \\
\hline
\end{tabular}

Dari hasil uji menggunakan Analisis Kendal tau di atas bahwa terdapat nilai signifikasi dari Output SPSS dan pengambilan keputusan setelah diketahui nilai signifikasi. Apabila nilai signifikasi $<0,05$ maka $\left(\mathrm{H}_{0}\right)$ ditolak dan Ha diterima, yang Andragogi: Volume 2 Nomor 2, 2020 
berarti terdapat hubungan antar variabel yang diteliti. Dan apabila nilai signifikasi $>0,05$ maka $\left(\mathrm{H}_{0}\right)$ diterima, yang berarti tidak ada hubungan antar kedua variabel. Berdasarkan hasil analisis diatas, didapaatkan nilai signifikasi antara Ketepatan perhitungan KKM terhadap Keberhasilan Belajar Siswa sebesar ,048. Yang berarti nilai signifikasi tersebut $<0,05$ sehingga dapat bermakna $\mathrm{H}_{0}$ ditolak dan Ha diterima, yang artinya terdapat hubungan antara Ketepatan Perhitungan KKM terhadap Keberhasilan Belajar Siswa Di MI Miftahul Ulum Sooko Wringinanom Gresik. Dari hasil output analisis korelasi kedua variabel dengan menggunakan program SPSS diatas nilai koefisien ( $\mathrm{r}$ ) korelasi Ketepatan Perhitungan KKM sebesar 0,600 berada pada interval koefisien 0,60 - 0,799 yang berarti menunjukkan tingkat hubungan yang Kuat.

\section{Simpulan}

Dari pemaparan penulis, dapat diambil kesimpulan tipologi manajemen lembaga pendidikan Islam di Nusantara (studi kasus di pondok pesantren AlKaromah kepanjen malang) terlihat dari pengembangan pesantren yang lebih cenderung kepada pengembangan pesantren secara modern, hal ini bisa dilihat dari hasil penelitian yang penulis laksanakan yaitu terlihat dalam kurikulum pesantren yang pengembangannya cenderung kepada mengembangkan madrasah diniah yang terbagi menjadi madrasah diniyah tingkat ula, wustha, dan ula. Tidak hanya pengembangan madrasah diniah saja, dalam pengembangan kurikulum yang ada di pesantren Al-Karomah mengembangkan kurikulum pesantren yang bersifat makro, meso dan mikro.

Berdasarkan dari pembahasan tersebut, data dan temuan yang peneliti uraikan sebagai berikut:

1. Dari hasil perhitungan yang diperoleh dari hasil observasi dan kuosioner tingkat ketepatan perhitungan Kriteria Ketuntasan Minimal (KKM) di MI Miftahul Ulum Sooko, berada pada kategori Baik. hal ini dapat dilihat dari hasil prosentase observasi siswa yang berjumlah $84,4 \%$.

2. Dari hasil perhitungan yang diperoleh dari hasil nilai belajar siswa di MI Miftahul Ulum Sooko Wringinanom Gresik, berada pada kategori Baik. hal ini dapat dilihat dari hasil prosentase nilai belajar siswa yang berjumlah 83,3\%.

Terkait pengaruh Ketepatan Perhitungan Kriteria Ketuntasan Minimal (KKM) terhadap keberhasilan belajar siswa di MI Miftahul Ulum Sooko Wringinanom Gresik yang dibuktikan oleh hasil perhitungan Analisis Korelasi Kendal Tau. Terbukti ada korelasi yang signifikan dari hasil output analisis korelasi kedua variabel dengan menggunakan program SPSS diatas nilai koefisien (r) korelasi 
Ketepatan Perhitungan Kriteria Ketuntasan Minimal (KKM) sebesar 0,600 berada pada interval koefisien 0,60 - 0,799 yang berarti menunjukkan tingkat hubungan yang Kuat.

\section{Daftar Rujukan}

Departemen Agama Provinsi Jawa Timur. 2009. Pedoman dan Implementasi Pengembangan KTSP di Madrasah Ibtidaiyah

Djamarah, Syaiful Bahri dan Aswan Zain. 2010. Strategi Belajar Mengajar. Jakarta : Rineka Cipta.

Djamarah, Syaiful Bahri. 2014. Guru dan Anak Didik Dalam Interaksi Edukatif. Jakarta : Rineka Cipta.

Pasal 3 UU RI Nomor 20. 2013. Sistem Pendidikan Nasional. Bandung : Citra Umbara.

Sa'dullah, Anwar \& Muhammad Fahmi Hidayatullah. 2020. Design Of Improving The Quality Of Human Resources Based On Islamic Schools In Anak Saleh Foundation, Malang City. Nazhruna: Jurnal Pendidikan Islam Vol. 3 No. 2.

Sagala, Syaiful. 2005. Konsep dan Makna Pembelajaran Untuk Membantu Memecahkan Problematika Belajar dan Mengajar. Bandung : Alfabeta.

Sugiyono. 2013. Metode Penelitian Kuantitatif, Kualitatif, dan R\&D. Bandung: CV. Alfabeta.

Syaifuddin, Mohammad. 2017. Implementasi Pembelajaran Tematik di Kelas 2 SD Negeri Demangan Yogyakarta. Jurnal Tadris,Vol 2. No.2.

Warsita, Bambang. 1982. Teknologi Pembelajaran. Bandung : Rineka Cipta.

Wiyono, Dwi Fitri. 2017. Pemikiran Pendidikan Islam: Konseptualisasi Pendidikan Karakter Dalam Perspektif Intelektual Islam Klasik. Jurnal Nidhomul Haq Vol. 2, No. 3. 